Article

\title{
Conservation for Sustainable Development: The Sustainability Evaluation of the Xijie Historic District, Dujiangyan City, China
}

\author{
Huaiyun Kou ${ }^{1, *} \mathbb{0}$, Jian Zhou ${ }^{1, *}$, Jie Chen ${ }^{2}$ and Sichu Zhang ${ }^{3}$ \\ 1 College of Architecture and Urban Planning, Institute for Advanced Study in Architecture and Urban-Rural \\ Planning, Key Laboratory of Ecology and Energy-saving Study of Dense Habitat of Ministry of Education, \\ Tongji University, Shanghai 200092, China \\ 2 Government of Juyuan Town, Dujiangyan City 611830, China; jiechen33@hotmail.com \\ 3 Shanghai Urban Construction Vocational College, Shanghai 200433, China; zhangsichu@succ.edu.cn \\ * Correspondence: khy@tongji.edu.cn (H.K.); zhouj@tongji.edu.cn (J.Z.); Tel.: +86-136-0196-4326 (H.K.); \\ +86-139-1660-0615 (J.Z.)
}

Received: 25 October 2018; Accepted: 4 December 2018; Published: 6 December 2018

\begin{abstract}
Historic districts have become a significant aspect of urban diversity and sustainable development, due to their dual attributes of cultural heritage and living community. This study aims to assess the influence of conservation efforts on the sustainable development of historic districts. Based on a literature review, this study designed a sustainability evaluation model that included twelve indicators and twenty-seven sub-indicators, in reference to heritage conservation, stakeholder participation, economic development, and planning and governance. The case study of the Xijie Historic District in Dujiangyan City, China, was selected to apply the model. Using data collected via questionnaire surveys and in-depth interviews, and using qualitative and quantitative combined methods and weighted averages, the model produced the sustainability index of the Xijie Historic District. Further examinations were performed and findings were explored, regarding the conservation efforts for the Xijie Historic District. Despite the research limitation of a lack of multi-sample verification, the results of the assessment are consistent with what is found in practice, demonstrating the validity of the model. The sustainability evaluation model can be applied to various historic districts and regions, by reassigning indicator weights to the different cases; the indicators system also provides references for research and practical applications for the conservation and sustainable development of other heritage types.
\end{abstract}

Keywords: sustainability evaluation; heritage conservation; historic district; China

\section{Introduction}

Sustainability has been introduced in the field of contemporary cultural heritage conservation, to achieve conservation goals, in order to preserve as much culture as possible, for the future generations [1]. Additionally, cultural heritage has been widely recognized as an integral element of urban diversity and a fertile ground for sustainable development [2-5], with a consensus emerging, both in policy and among scholars, that culture needs to be independently presented as the fourth pillar of sustainable development, alongside the environmental, economic, and social pillars [6-10]. In the international heritage conservation field, the conversation has changed from 'conservation versus sustainability' to 'conservation for sustainability' [11].

A review of the sustainability and cultural heritage literature shows that most research has focused on discussing the interrelationship between heritage and sustainability, or sustainable heritage tourism. However, relatively few studies have focused, specifically, on the conservation efforts that includes 
heritage conservation, environmental improvement, or types of business promotion [12,13]. Moreover, few evaluation tools are universally accepted for sustainability appraisals [14]. A research gap exists in the evaluation of conservation and development performance, in the framework of sustainability.

For historic districts, a type of living heritage that contains people's daily lives, sustainability research pays most attention toward addressing the dual objectives of historic preservation and community development $[15,16]$.

This research aims to develop a model to assess the influence of conservation efforts on the sustainable development of historic districts, by introducing a set of weighted, scored indicators. By applying the model, the index of sustainability of a historic district can be measured, and the conservation efforts related to each indicator, can be identified and evaluated.

This research introduces the case study of the Xijie Historic District in the Sichuan Province, China, in order to evaluate its sustainability and test the applicability of the presented sustainability model. The Xijie Historic District, which is located in Dujiangyan City, was devastated by the 2008 Wenchuan earthquake that shook the Sichuan Province. The conservational reconstruction project of the Xijie Historic District (the Xijie project, in brief) began in 2009 and accomplished in 2012, making this District one of the most attractive tourist destinations in Dujiangyan City. However, the District is facing sustainable developmental challenges due to over-commercialization, the declining number of residents, and threats, such as mudslides and humidity. It is, therefore, necessary to carry out a review and evaluation of the conservation and development of the Xijie Historic District from the perspective of sustainability. The authors have been involved in the post-earthquake conservational reconstruction project of Xijie, since the beginning of its implementation, and have tracked the changes in the project, while accumulating a large amount of research data, over the past ten years.

\section{Cultural Heritage and Sustainable Development}

Cultural heritage, as a local resource, is tightly linked to local sustainable development. They mutually reinforce each other in an upward and sustainable spiral, raising concerns from various groups in the culture, architecture, urban planning, community, and tourism fields [17-20].

Organizations under the mantle of the United Nations are active promoters of cultural heritage for sustainable development. The New Urban Agenda (NUA) recognises the role of cultural heritage in sustainable urban development [21]. The '2030 Agenda for Sustainable Development' set seventeen sustainable development goals supported by one hundred and sixty-nine targets, one of which advocates efforts to protect and safeguard the world's natural and cultural heritage [22]. However, this target has been criticized as being a weak reference because it is integrated with natural heritage [23]. The 'Policy on the integration of a sustainable development perspective into the processes of the World Heritage Convention' aims to assist all stakeholders in contributing to sustainable development [5]. The 'World Heritage and Sustainable Tourism Programme' intends to incorporate principles of sustainable tourism into the framework of the world heritage convention, issuing the Action Plan and a toolkit, to guide worldwide pilot studies [24]. The Concept Note on cultural heritage, issued by the International Council on Monuments and Sites (ICOMOS), also stresses the importance of heritage in sustainable development, and of the integration of cultural heritage into urban development [25].

Academic research studies have explored the vital role of sustainable development concepts when they are integrated into the cultural heritage. For example, Sharpley (2000) studied the relationship between sustainable development and heritage tourism [26]. Cole (2004) conducted considerable work on sustainability and mining heritage tourism [27]. Rodwell (2003) discussed the relationship between a successfully built heritage conservation, cultural identity, and the wider scope of sustainability, with emphasis on communality, as an approach [28]. Wilson and Boyle (2006) provided approaches to collaboration between organizations of world heritage sites [29]. Landorf (2009) argued that the key principles of sustainable practice for world heritage should be codified in a long-term policy, using holistic planning processes and involving multiple stakeholders [13]. Such debates on how to manage the sustainability of cultural heritage site are still raising concerns. This paper, therefore, suggests 
that the first stage in conservation should involve determining whether cultural heritage sites are developed in a sustainable manner, before starting the decision-making process.

\section{Historic District Conservation and Sustainability Evaluation}

The concepts of sustainability appraisal, sustainability assessment, and sustainability evaluation can all be employed to measure the efforts for sustainable development, at selected heritage sites. In the United Kingdom, a sustainability appraisal is described as a systematic process that should be carried out when a local plan is prepared [30]. The targets of sustainability assessment are used for proposing actions (in most cases, projects, programs, plans, or policies) [31]. The sustainability evaluation usually narrows down to the scope of the targeted assessments, at the project or program level.

Many studies attempt to examine the conservation and regeneration projects in historic districts, through a sustainable development framework. Comparing a high degree of concern on social sustainability among these studies [32,33], only a few studies provide a comprehensive understanding related to the four dimensions of sustainability (environmental, social, economic, and cultural dimensions) $[19,34,35]$. In addition, most articles concerning the four dimensions belong to heritage tourism studies [36-42], while the conservation and development of historic districts are not necessarily combined with tourism. Moreover, tourist-oriented conservation has been criticized for interfering with the daily lives of the locals [43-45]. Boeri (2016) set the 'balance between preservation, improvement of environmental performances, and social inclusion' as the aim to create sustainable and creative cultural districts, and introduced a 'spatial integrated approach', which represented an inter-disciplinary methodology for a sustainability evaluation of the heritage-led regeneration [46].

The principles of sustainability for historic district conservation has been widely accepted, in the academic field in China. However, the evaluation of the historic district conservation often departs from the sustainability perspectives, practised primarily in architecture and urban planning field, with a focus on the heritage, per se, in relation to the historical layout, vernacular buildings, facilities, and intangible heritage, such as traditional architectural crafts and festivals [47-49]. Although both the security of the local livelihoods and the community involvement approach are always concerned, while assessing the performance of historic district conservation, they are employed to address the criteria of authenticity and integrity, and are not specifically considered from a sustainable point of view [50-52]. Development-oriented projects have continued to prevail throughout the past few decades in China, such as demolition and relocation, newly built pseudo-historic streets, staged authenticity for tourists, over-commercialization, gentrification, and other such processes [52-54]. Therefore, evaluating the sustainability of conservation performance and feedback to the conservation methods would fill the research gap in the sustainable development of historic districts.

Qualitative analysis remains the primary method for the assessment of historic districts, while quantitative approach is expected to reduce bias, in the process of identifying the conservation efforts $[55,56]$. Indicators play an essential role in sustainability evaluation to provide quantitative performance measures [23,57-59], while few studies on indicators can support the relationship between cultural heritage conservation and urban sustainable development [23]. Therefore, the relatively well-explored indicators system, in the field of urban sustainability evaluation, provides a reference for the design of the evaluation indicators and the structures, in this study $[60,61]$. 


\section{Research Methodology}

\subsection{Design of Indicators}

The indicators of the sustainability evaluation of historic districts conservation were designed after reviewing the existing indicators, in relation to sustainability assessment and the characteristics of the historic districts. The indicators system in this study contains twelve first-layer indicators and twenty-seven sub-indicators related to the following four categories-heritage conservation, stakeholder participation, economic development, and planning and governance. The indicators, along with the reasons for their selection, are listed in Tables 1-4.

The above four categories were developed from the four pillars of sustainable development, namely, the environmental, economic, social, and cultural pillars. Heritage conservation evaluated the historic district conservation effects, including the tangible and intangible heritages, and their settings, addressing the environmental and cultural pillars. Stakeholder participation assessed the social impact of conservation implementation, considering two key stakeholders-the residents and the public. Economic development emphasized the potential and capacity of development, instead of the current economic situation. Planning and governance measured the capacity of public decision-making and management, by evaluating the plans, policies, and governmental organizations, reflecting the effectiveness of management, in terms of the four aspects of sustainable development. 
Table 1. Heritage conservation

\begin{tabular}{|c|c|c|c|c|c|c|}
\hline \multirow{2}{*}{$\begin{array}{c}\text { Indicator } \\
\text { Sub-indicator }\end{array}$} & \multicolumn{2}{|c|}{ Tangible Heritage } & \multicolumn{2}{|c|}{ Intangible Heritage } & \multicolumn{2}{|c|}{ Environmental Improvement } \\
\hline & Historic layout & $\begin{array}{l}\text { Historic buildings } \\
\text { and elements }\end{array}$ & $\begin{array}{c}\text { Traditional } \\
\text { craftsmanship }\end{array}$ & Customs and festivals & $\begin{array}{l}\text { Public facilities and } \\
\text { infrastructure }\end{array}$ & $\begin{array}{l}\text { Public space and } \\
\text { sanitation }\end{array}$ \\
\hline Questions & H1 & $\mathrm{H} 2$ and $\mathrm{H} 3$ & $\mathrm{H} 4$ & $\mathrm{H} 5$ and $\mathrm{H} 6$ & $\mathrm{H} 7$ and $\mathrm{H} 8$ & $\mathrm{H} 9$ and $\mathrm{H} 10$ \\
\hline Reasons for indicator selection & \multicolumn{2}{|c|}{ Authenticity and integrity of the built heritage } & \multicolumn{2}{|c|}{ Continuity of the intangible heritage } & \multicolumn{2}{|c|}{ Settings of heritage } \\
\hline Interviewee & \multicolumn{4}{|c|}{ Residents in or around the historic district (households, merchants); experts } & \multicolumn{2}{|c|}{$\begin{array}{l}\text { Residents in or around the historic district } \\
\text { (households, merchants); } \\
\text { tourists (local and foreign); experts }\end{array}$} \\
\hline Scoring criteria & \multicolumn{6}{|c|}{ A to $E$ correspond to scores from 5 to 1} \\
\hline
\end{tabular}

Table 2. Stakeholder participation.

\begin{tabular}{|c|c|c|c|c|c|c|}
\hline Indicator & \multicolumn{2}{|c|}{ Community Participation } & \multicolumn{2}{|c|}{ Community Satisfaction } & \multicolumn{2}{|c|}{ Public Consciousness of Conservation } \\
\hline Sub-indicator & $\begin{array}{l}\text { The scope of participation } \\
\text { (aspects the community } \\
\text { involved in) }\end{array}$ & $\begin{array}{l}\text { The depth of } \\
\text { participation } \\
\text { (degrees the community } \\
\text { can decide) }\end{array}$ & $\begin{array}{l}\text { Satisfaction with the } \\
\text { implementation } \\
\text { process of the } \\
\text { conservation project }\end{array}$ & $\begin{array}{l}\text { Satisfaction with the } \\
\text { results of the } \\
\text { conservation project }\end{array}$ & $\begin{array}{l}\text { Publicity and } \\
\text { education }\end{array}$ & $\begin{array}{l}\text { Society's participation } \\
\text { in conservation }\end{array}$ \\
\hline Reasons for indicator selection & \multicolumn{2}{|c|}{ Measuring the degree of the community involvement } & \multicolumn{2}{|c|}{$\begin{array}{l}\text { Measuring the overall satisfaction with the } \\
\text { implementation and result of the conservation } \\
\text { project }\end{array}$} & \multicolumn{2}{|c|}{$\begin{array}{l}\text { Stakeholders' cognition and enthusiasm for the } \\
\text { heritage conservation }\end{array}$} \\
\hline Questions & S1 & S2 & S3 & S4-S6 & S7 & S8 \\
\hline Interviewees & \multicolumn{4}{|c|}{ Residents living in the historic district during the implementation of the project } & \multicolumn{2}{|c|}{$\begin{array}{c}\text { Residents in or around the historic } \\
\text { district(households, merchants); tourists; } \\
\text { experts }\end{array}$} \\
\hline Scoring criteria & \multicolumn{6}{|c|}{ A to $E$ correspond to scores from 5 to 1} \\
\hline
\end{tabular}


Table 3. Economic development.

\begin{tabular}{|c|c|c|c|c|c|c|c|}
\hline \multicolumn{2}{|c|}{ Indicator } & \multicolumn{2}{|c|}{ Employment } & \multicolumn{2}{|c|}{ Profitability } & \multicolumn{2}{|c|}{ Types of Business } \\
\hline \multicolumn{2}{|c|}{ Sub-indicator } & $\begin{array}{l}\text { Full-time and permanent } \\
\text { employment }\end{array}$ & Local employment & $\begin{array}{l}\text { The annual average } \\
\text { growth rate of gross } \\
\text { production }\end{array}$ & Housing vacancy rate & $\begin{array}{l}\text { Business types and } \\
\text { proportions }\end{array}$ & Local compatibility \\
\hline \multicolumn{2}{|c|}{ Reasons for indicator selection } & $\begin{array}{l}\text { Measuring the proportion } \\
\text { of stable employment }\end{array}$ & $\begin{array}{l}\text { Measuring the proportion } \\
\text { of local employment }\end{array}$ & $\begin{array}{l}\text { Measuring the growth of } \\
\text { gross production }\end{array}$ & $\begin{array}{l}\text { Measuring the economic } \\
\text { vitality of the district }\end{array}$ & $\begin{array}{l}\text { Measuring the diversity of } \\
\text { the business }\end{array}$ & $\begin{array}{l}\text { Measuring if the business } \\
\text { types match local } \\
\text { characteristics }\end{array}$ \\
\hline \multirow{5}{*}{ Scoring criteria } & 5 & $81-100 \%$ & $81-100 \%$ & More than $10 \%$ & $\begin{array}{l}\text { No vacant houses; house } \\
\text { rents are flat or rising year } \\
\text { by year. }\end{array}$ & Highly diversified & All match \\
\hline & 4 & $61-80 \%$ & $61-80 \%$ & $6.7-10 \%$ & $\begin{array}{l}\text { No vacant houses; house } \\
\text { rents fall year by year }\end{array}$ & Diversified & Most match \\
\hline & 3 & $41-60 \%$ & $41-60 \%$ & $3.4-6.6 \%$ & $\begin{array}{c}\text { Housing vacancy rate is } \\
\text { less than } 5 \%\end{array}$ & Moderately diversified & Moderately match \\
\hline & 2 & $21-40 \%$ & $21-40 \%$ & $0-3.3 \%$ & $\begin{array}{l}\text { Housing vacancy rate } \\
\text { from } 5 \%-10 \%\end{array}$ & Little diversified & Few match \\
\hline & 1 & Below or equal to $20 \%$ & Below or equal to $20 \%$ & Below or equal to $0 \%$ & $\begin{array}{l}\text { Housing vacancy rate is } \\
\text { higher than } 10 \%\end{array}$ & Lack of diversity & None match \\
\hline \multicolumn{2}{|c|}{ Interviewees } & \multicolumn{6}{|c|}{ Community Committee; Ancient Town Management Office } \\
\hline
\end{tabular}


Table 4. Planning and governance.

\begin{tabular}{|c|c|c|c|c|c|c|c|c|c|}
\hline \multirow{2}{*}{$\begin{array}{c}\text { Indicator } \\
\text { Sub-indicator }\end{array}$} & \multicolumn{3}{|c|}{ Planning and Policies } & \multicolumn{2}{|c|}{ Governance } & \multicolumn{4}{|c|}{ Risk Management } \\
\hline & $\begin{array}{l}\text { Formulating plan and } \\
\text { policies }\end{array}$ & $\begin{array}{l}\text { Implementing } \\
\text { planning and policies }\end{array}$ & $\begin{array}{l}\text { Formulation of } \\
\text { supplementary } \\
\text { policies }\end{array}$ & Governance system & $\begin{array}{l}\text { Effectiveness of } \\
\text { governance }\end{array}$ & $\begin{array}{l}\text { Tourism } \\
\text { management }\end{array}$ & $\begin{array}{l}\text { Management of } \\
\text { remodelling, } \\
\text { decoration, and } \\
\text { transformation }\end{array}$ & $\begin{array}{l}\text { Public security } \\
\text { management }\end{array}$ & $\begin{array}{l}\text { Emergency } \\
\text { warning }\end{array}$ \\
\hline $\begin{array}{l}\text { Reasons for } \\
\text { indicator } \\
\text { selection }\end{array}$ & $\begin{array}{l}\text { The scientificity and } \\
\text { rationality of } \\
\text { planning and policies; } \\
\text { whether the planning } \\
\text { and policies were } \\
\text { transparent to the } \\
\text { public at the } \\
\text { formulation stage }\end{array}$ & $\begin{array}{l}\text { Whether the } \\
\text { provisions of the plan } \\
\text { were effectively } \\
\text { implemented; } \\
\text { whether the planning } \\
\text { was transparent to } \\
\text { the public at the } \\
\text { implementation stage; } \\
\text { whether there were } \\
\text { revisions in the } \\
\text { implementation } \\
\text { process }\end{array}$ & $\begin{array}{l}\text { Whether there were } \\
\text { supplementary } \\
\text { policies during and } \\
\text { after the process of } \\
\text { implementation }\end{array}$ & $\begin{array}{l}\text { Whether a complete } \\
\text { management } \\
\text { system had been } \\
\text { established } \\
\text { according to } \\
\text { regulations } \\
\text { and plans; } \\
\text { whether a special } \\
\text { management } \\
\text { institution had been } \\
\text { established; } \\
\text { whether the human } \\
\text { resources of the } \\
\text { management } \\
\text { institutions } \\
\text { were sound; } \\
\text { whether the } \\
\text { management } \\
\text { organization was } \\
\text { operating regularly; } \\
\text { whether there was } \\
\text { law } \\
\text { enforcement right } \\
\end{array}$ & $\begin{array}{l}\text { Measuring the } \\
\text { executive ability } \\
\text { and } \\
\text { implementation } \\
\text { efficiency of } \\
\text { governance }\end{array}$ & $\begin{array}{l}\text { Management of } \\
\text { tourists' capacity, } \\
\text { tourists' negative } \\
\text { behaviour, etc. }\end{array}$ & $\begin{array}{c}\text { Risks from shop } \\
\text { decoration, } \\
\text { rebuilding, public } \\
\text { space } \\
\text { transformation, etc. }\end{array}$ & $\begin{array}{l}\text { Maintenance and } \\
\text { management of } \\
\text { public security in } \\
\text { the district }\end{array}$ & $\begin{array}{c}\text { Emergency } \\
\text { management } \\
\text { system for floods, } \\
\text { mudslides, } \\
\text { earthquake, fire and } \\
\text { other hazards }\end{array}$ \\
\hline $\begin{array}{l}\text { Scoring } \\
\text { criteria }\end{array}$ & \multicolumn{9}{|c|}{ The degrees of the performance from high to low correspond to scores from 5 to 1} \\
\hline Interviewees & \multicolumn{9}{|c|}{$\begin{array}{l}\text { Officials in the Urban Planning Bureau } \\
\text { (The evaluators need to verify the authenticity after obtaining the data) }\end{array}$} \\
\hline
\end{tabular}




\subsection{Establishing Sustainability Evaluation Model}

A scoring and weighting approach was employed to rate the importance of indicators for the sustainable development of historic districts [61-64]. According to the Delphi method, experts are invited to score the indicators, from which the weight values can be measured by the arithmetic average method. The weight coefficient of each indicator is calculated as its weight values divided by the sum of the weight values of all indicators (Equation (2)).

The conservation effect concerning each indicator can be measured by the score obtained from the questionnaire and the interview surveys.

The sustainability index of the historic district development is equivalent to the sum of each indicator's sustainability index, which is equal to the score of the indicator, multiplied by its weight coefficient (Equation (1)):

$$
\begin{gathered}
\mathrm{I}=\sum_{k=1}^{n} \mathrm{w}_{k} \mathrm{~s}_{k} \\
\mathrm{w}_{k}=\frac{\mathrm{v}_{k}}{\sum_{k=1}^{n} \mathrm{v}_{k}}
\end{gathered}
$$

I: sustainability index; w: weight coefficient of indicators; s: score of indicators; v: weight value of indicators

\subsection{The Case of the Xijie Historic District}

The Xijie District is located in the buffer zone of the World Heritage Site of Dujiangyan Irrigation System, which covers an area of about 40,000 $\mathrm{m}^{2}$ (Figures 1 and 2).

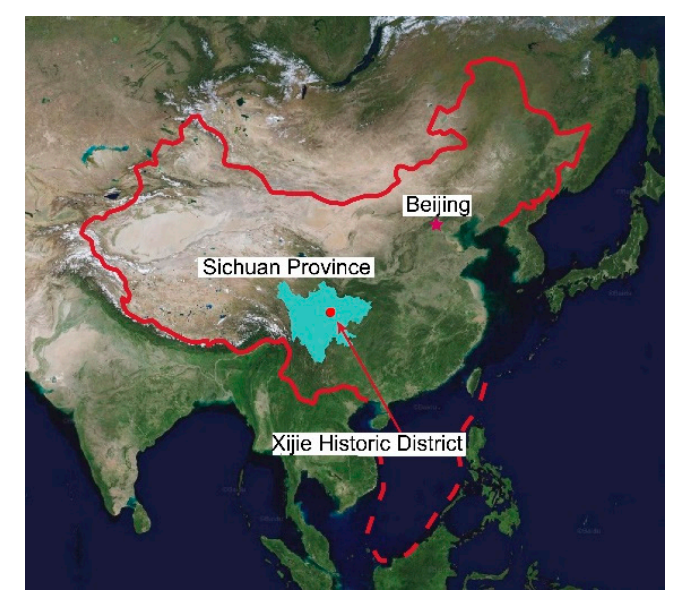

Figure 1. Location of the Xijie District in China. 


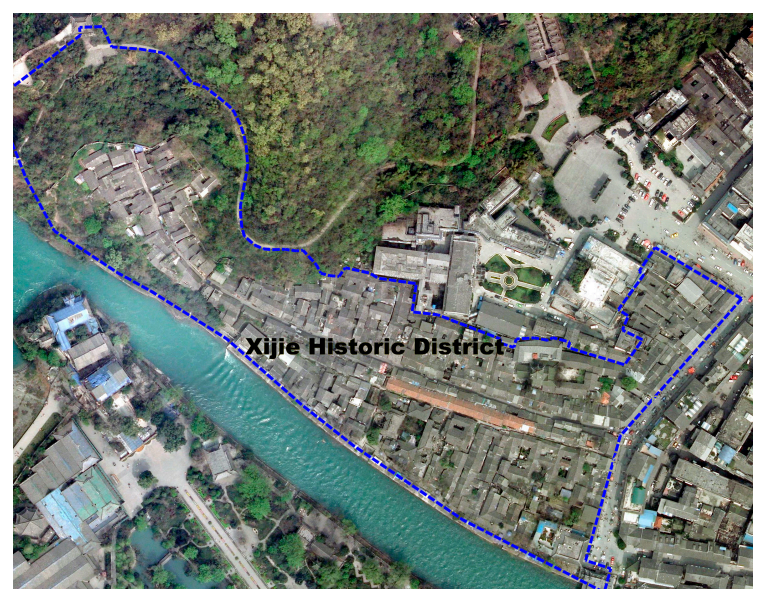

Figure 2. The scope of the Xijie District.

The Xijie District was the start of the Songmao Ancient Trade Route, which ran from the Chengdu Plain to the Tibetan Plateau. The existing layout was built between the years 1522 and 1566, and includes the ruins of the Ming Dynasty city walls, religious sites consisting of two mosques, and some traditional houses in the West-Sichuan architectural style of the Southwest China (Figure 3). The main street, which is about $390 \mathrm{~m}$ long and $4 \mathrm{~m}$ wide, passes through the middle of the District. Before the reconstruction project, this residential district was densely populated by four hundred and thirty-eight families, with more than $70 \%$ of the residents tracing their ancestral lineage to the local area, and practising traditions such as the Dam Feast (an outdoor banquet held along the main street; Figure 4) [65].

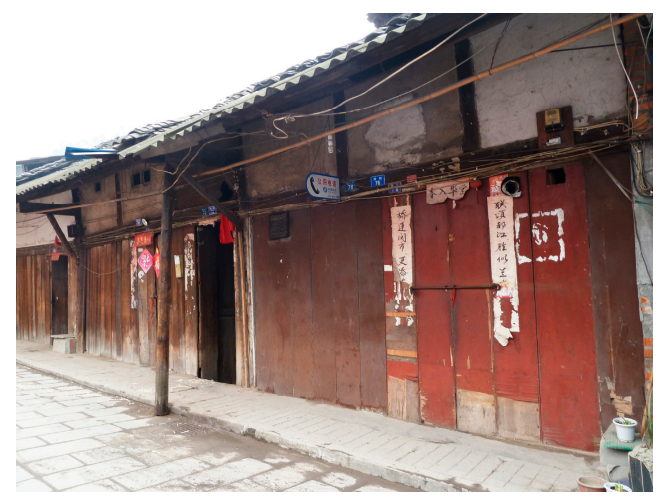

Figure 3. A West-Sichuan style dwelling.

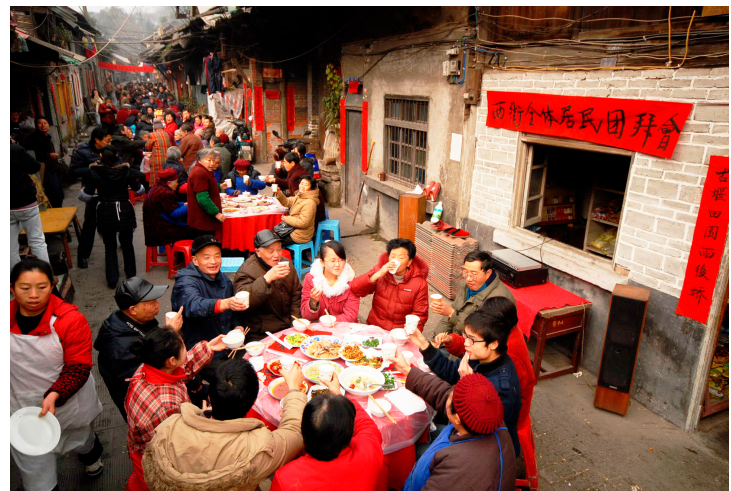

Figure 4. The Dam Feast in 2009. 
Prior to the 2008 Wenchuan earthquake, the wooden structures of the traditional buildings had deteriorated due to a lack of maintenance, and an infrastructure that was in poor conditions. Together with high density and insufficient housing, the community was facing a recession. The earthquake made matters worse for this neighbourhood, with over $80 \%$ of the buildings no longer suitable for living [66].

The conservational reconstruction project of Xijie was designated as part of Dujiangyan's integral post-earthquake reconstruction efforts, with multiple objectives regarding historic preservation, poverty alleviation, and local development. To address these objectives, the Complete Plan of Conservation and Reconstruction of the Xijie Historic District in Dujiangyan City (Conservation Plan, in brief) adopted the UNESCO Historic Urban Landscape (HUL) approach, which highlights the value of a living heritage being contingent on its historical layers $[67,68]$. In this light, the Conservation Plan ensured the diversity of the District by classifying the buildings into historic buildings, traditional buildings, and new buildings, according to their locations, ages, architectural styles, and condition, while being subjected to interventions of repair and restoration, rehabilitation, and contextual design, respectively. The Conservation Plan also emphasize the revitalization of the neighbourhood by improving living conditions, enhancing the infrastructure and public facilities, and introducing commercial and cultural services into the district.

The local government adopted a community participation approach by starting the project with a portion of the residents voluntarily relocating. Residents chose either to stay in their neighbourhood or move, at no cost, to new dwellings provided by the municipal government, about five kilometres away from Xijie. A total of $48 \%$ of the households moved, which reduced the residential density of Xijie. The residents who stayed ( $52 \%$ of households) participated in housing reconstruction, in accordance with the requirements of the Conservation Plan, with a subsidy provided by the government that was equal to half of the housing construction price. Almost all of the remaining households joined the reconstruction process, with the exception of one family, who preferred to keep the status quo. Meanwhile, the municipal government improved the public spaces and infrastructures. Following the completion of the reconstruction in 2012, the neighbourhood environment and housing conditions had been significantly improved (Figure 5). New businesses settled in quickly, mainly restaurants and bars targeted at local people, and business development reached a climax in 2015. Subsequently, this kind of commercial development was depressed and gradually transformed into tourism commodities, driven by the market (Figure 6).

The selection of a case study should be based on its representativeness [69]. As a result of the 2008 earthquake, the Chinese government established a special fund for the post-earthquake reconstruction of the Xijie Historic District, providing policy support for humane care of the suffering people, with no forced relocation. These policies are consistent with the current trends in China, regarding community involvement, property rights protection, and better financial backing, which are integral to the global heritage conservation context, at present. The implementation of the Xijie project began in 2009, and its goals were quickly accomplished by 2012. The housing, infrastructure, and the environment were improved, meanwhile, the historical urban fabric and traditional characteristics of the Xijie Historic District were retained. Since then, Xijie has experienced six years of development. The analysis of this case study, therefore, contains long-term observations made over a decade, at the different stages of development. Although to a great extent it is a reconstruction project, it is still a suitable case for this study. 

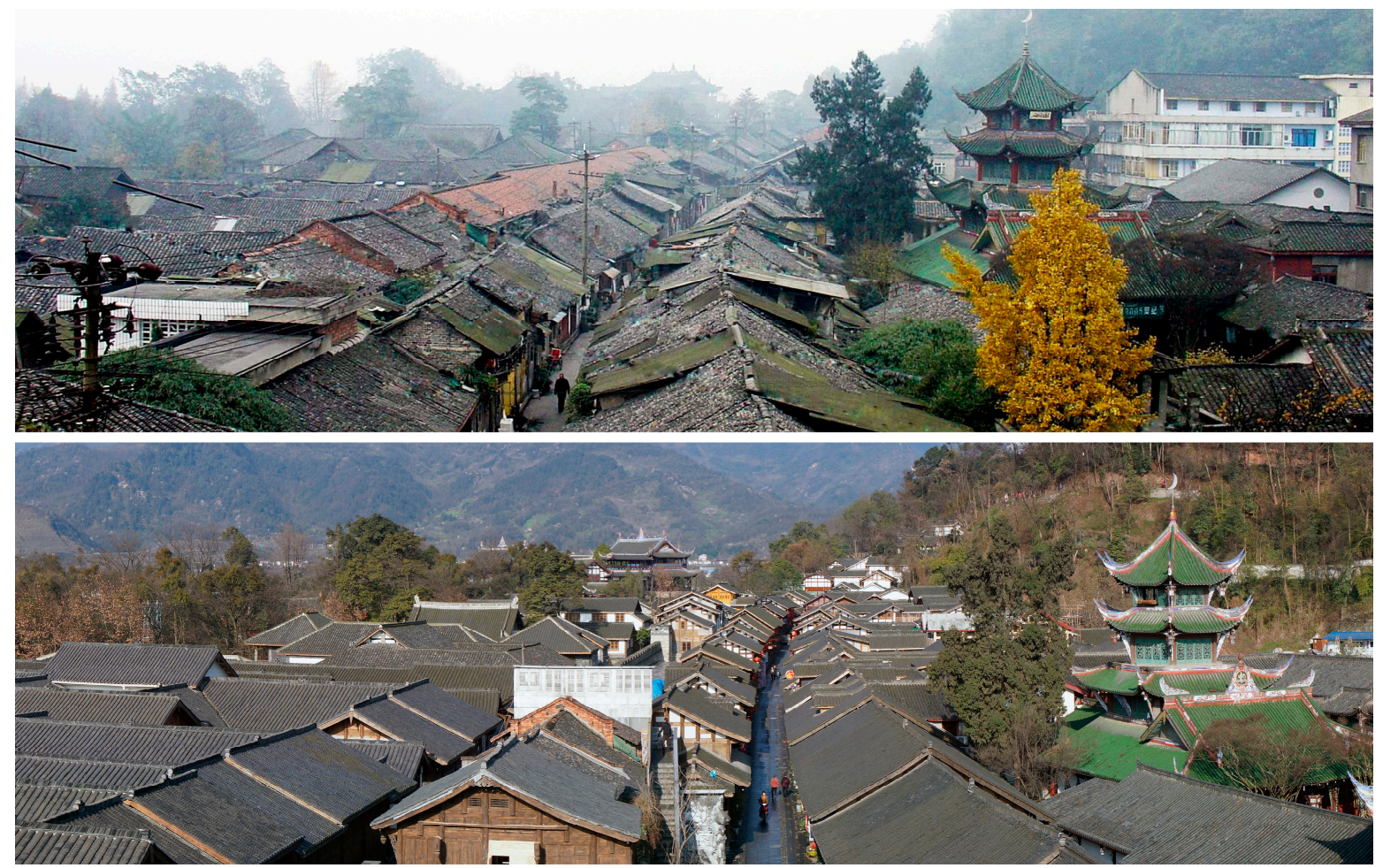

Figure 5. Aerial view of the Xijie Historic District before the project in 2008 (up) and after (down) the project in 2014.

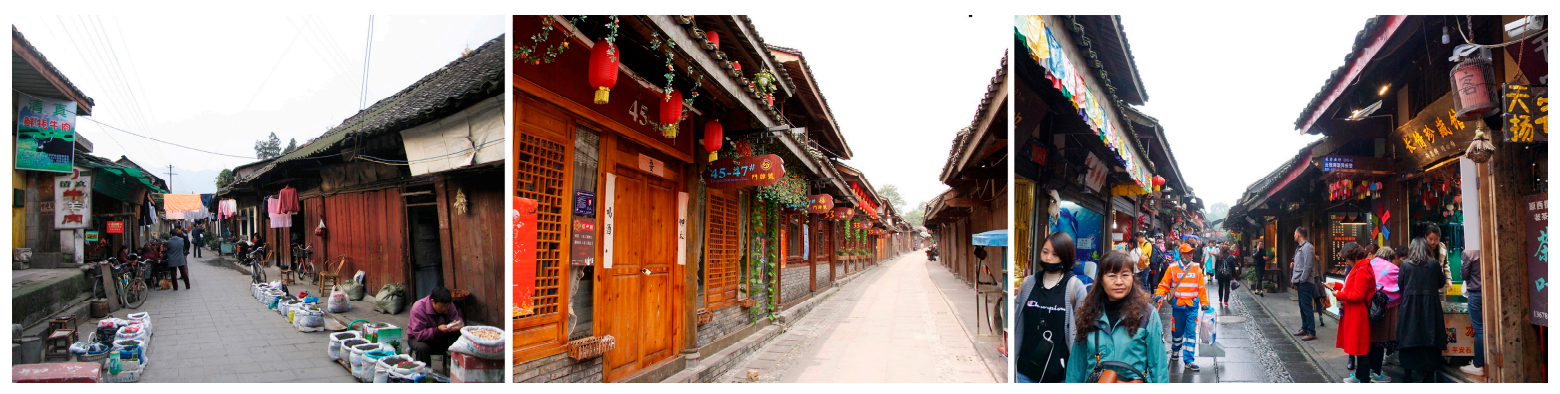

Figure 6. Street view of the Xijie Historic District in 2008 (left); 2014 (middle); and 2018 (right).

\subsection{Design of Questionnaires and Interview Questions}

Four structure modules of questionnaires were set corresponding to the four dimensions of heritage conservation (Module $\mathrm{H}$ ), stakeholder participation (Module S), economic development (Module E), and planning and governance (Module G) (Appendix B: Structure Modules of Questionnaires). The questions were designed to address the sub-indicators. Each sub-indicator in Modules $\mathrm{H}$ and $\mathrm{S}$ contained one or two questions (Tables 1 and 2), while the interview questions in Modules E and G were broader and did not strictly correspond to the indicators.

Four questionnaires were developed, according to the interviewee groups, who relate to the questions in Modules H and S. Questionnaire 1, for the Xijie residents and merchants, included all of the questions in the two modules; questionnaire 2, for the residents around Xijie, contained most of the questions, except for the last question, in Module $S$, about neighbourhood identity; questionnaire 3 , for the tourists, skipped the questions not pertaining to them, such as details about the Xijie implementation process; questionnaire 4, for the experts, skipped questions relating to activities they were not involved in during the implementation process. 
Two sets of interview questions were created to gather data regarding the economic development (Module E) and the planning and governance (Module G), respectively.

Additionally, to provide supplementary data for this study, two open-ended questions were added to all questionnaires and interviews regarding the interviewee's perceptions of the greatest achievement of Xijie and the largest problem facing this District.

\subsection{Data Collection}

Questionnaires and interview surveys were conducted in May 2018. A total of three hundred and eleven validated questionnaires were collected in relation to the dimensions of heritage conservation and stakeholder participation, including one hundred validated questionnaires completed by the Xijie residents and merchants, one hundred and one questionnaires completed by the residents living around the Xijie Historic District, a hundred questionnaires completed by the visitors who were recruited from around the boundaries of $\mathrm{Xijie}$, and ten questionnaires completed by experts. Taking into account the two hundred and eighty residents and merchants in the Xijie neighbourhood, the approximately two thousand residents living close to the District, and the average of four thousand daily visitors to Xijie, this total of three hundred and eleven questionnaires constituted a practical sample size for data collection.

In-depth interviews were conducted to accumulate the data on the economic development and governance dimensions. The Community Committee and the Ancient Town Management Office provided the economic development data, and two senior local planners and a government officer from the Dujiangyan City, provided the governance data.

Ten experts were invited to rate the weights of the sub-indicators. The chosen experts were familiar with the Xijie District or the Xijie project, and those from different cities or countries, with different professional backgrounds were preferred, in order to mitigate bias and enhance the representativeness of the expert groups [70]. The experts were from the U.S.A, Canada, and China (Shanghai, Chengdu, and Dujiangyan City), with their backgrounds including heritage conservation, urban planning, architecture, tourism development, urban sociology, and anthropology. Experts were requested to assign scores reflecting the importance of the sub-indicators (Appendix A). All of the sub-indicators were awarded a score of 1-5 ( $1=$ unimportant, $2=$ of little importance, $3=$ moderately important, $4=$ important, and $5=$ very important) (Appendix A) [71]. Considering the diverse characteristics of historic districts, some indicators could be assigned zero points when they did not exist in a historic district, and would, therefore, be removed from the analysis process. For instance, a residential neighbourhood with no tourism would have an indicator of carrying a capacity score of zero, which would be excluded from the indicator consideration.

\subsection{Data Analysis}

The weight values reflected the importance of the indicators for the sustainable development of the Xijie Historic District, while the scores of conservation performance addressed the actual effects of the efforts, in relation to the indicators.

The calculated arithmetic means of the weight values and conservation performance scores are shown in Tables 5-8. For the heritage preservation and stakeholder participation dimensions, the scores of conservation performance were obtained directly from the questionnaires. The economic development, and planning and governance dimensions, involved a classification process that required identifying and coding contents to interpret the data, by converting the qualitative data obtained from the interview questions into quantitative statistics [72,73]. The most negative assessment was represented by a score of 1 , and the most positive description by a score of 5 . Scores were assigned to the remaining options so that the differences in the numbers were representative of the differences in the strength of the preference. 
By incorporating the weight values and scores of the sub-indicators in Tables 5-8 into the sustainability index equations in Section 4.2 (Equations 1 and 2), the sustainability index of Xijie was calculated to be 3.45 points (the maximum score was 5).

The difference between the weight value and score of each indicator reflected the gap between the actual performance and the expected effect (Tables 5-8). The larger the difference, the bigger the gap, which means that more efforts were required to reach sustainability.

The arithmetic average of the sub-indicator weight values and scores provided the weight values and scores of first-layer indicators (Table 9), which present an overview of the conservation performances of the twelve indicators. 
Table 5. Weight values and scores of the sub-indicators of heritage conservation.

\begin{tabular}{cccccc}
\hline Indicators & \multicolumn{2}{c}{ Tangible Heritage } & \multicolumn{2}{c}{ Intangible Heritage } & Environmental Improvement \\
\hline Sub-indicators & Historic layout & Historic buildings and elements & Traditional craftsmanship & Customs and festivals & Public facilities and infrastructure \\
Weight value & 5 & 4.8 & 3.8 & 3 & 4.6 \\
Score & 4 & 4 & 3 & 3 & 4 \\
Difference & 1 & 0.8 & 0.8 & 0 & 4.6 \\
\hline
\end{tabular}

Table 6. Weight values and scores of the sub-indicators of stakeholder participation.

\begin{tabular}{|c|c|c|c|c|c|c|}
\hline \multirow{2}{*}{$\begin{array}{c}\text { Indicators } \\
\text { Sub-indicators }\end{array}$} & \multicolumn{2}{|c|}{ Community Participation } & \multicolumn{2}{|c|}{ Community Satisfaction } & \multicolumn{2}{|c|}{ Public Consciousness of Conservation } \\
\hline & $\begin{array}{l}\text { The scope of the participants of } \\
\text { the Xijie project }\end{array}$ & $\begin{array}{l}\text { The depth of the participants of } \\
\text { the Xijie project }\end{array}$ & $\begin{array}{c}\text { Stakeholders' satisfaction with } \\
\text { the implementation of the Xijie } \\
\text { project }\end{array}$ & $\begin{array}{l}\text { Stakeholders' satisfaction with } \\
\text { the Xijie project results }\end{array}$ & $\begin{array}{l}\text { Publicity and } \\
\text { education }\end{array}$ & $\begin{array}{l}\text { Society's participation in } \\
\text { heritage conservation }\end{array}$ \\
\hline Weight value & 4.1 & 3.7 & 4.3 & 4.3 & 4.5 & 4.5 \\
\hline Score & 4 & 4.5 & 4 & 4 & 4 & 3 \\
\hline Difference & 0.1 & -0.8 & 0.3 & 0.3 & 0.5 & 1.5 \\
\hline
\end{tabular}

Table 7. Weight values and scores of the sub-indicators of economic development.

\begin{tabular}{|c|c|c|c|c|c|c|}
\hline \multirow{2}{*}{$\begin{array}{c}\text { Indicators } \\
\text { Sub-indicators }\end{array}$} & \multicolumn{2}{|c|}{ Employment } & \multicolumn{2}{|c|}{ Profitability } & \multicolumn{2}{|c|}{ Types of Business } \\
\hline & $\begin{array}{c}\text { Full-time and permanent } \\
\text { employment }\end{array}$ & Local employment & $\begin{array}{l}\text { Annual average growth rate of } \\
\text { gross production }\end{array}$ & Housing vacancy rate & Business types and proportions & Local compatibility \\
\hline Weight value & 3.8 & 4.2 & 3.8 & 4 & 4.1 & 4.2 \\
\hline Score & 5 & 1 & 3 & 5 & 2.5 & 1 \\
\hline Difference & -1.2 & 3.2 & 0.8 & -1 & 1.6 & 3.2 \\
\hline
\end{tabular}

Table 8. Weight values and scores of the sub-indicators of planning and governance.

\begin{tabular}{|c|c|c|c|c|c|c|c|c|c|}
\hline \multirow{2}{*}{$\begin{array}{c}\text { Indicators } \\
\text { Sub-indicators }\end{array}$} & \multicolumn{3}{|c|}{ Planning and Policies } & \multicolumn{2}{|c|}{ Governance } & \multicolumn{4}{|c|}{ Risk Management } \\
\hline & $\begin{array}{l}\text { Formulating the plan } \\
\text { and policies }\end{array}$ & $\begin{array}{l}\text { Implementing the plan } \\
\text { and policies }\end{array}$ & $\begin{array}{c}\text { Formulation of } \\
\text { supplementary policies }\end{array}$ & $\begin{array}{l}\text { Governance } \\
\text { system }\end{array}$ & $\begin{array}{l}\text { Effectiveness } \\
\text { of governance }\end{array}$ & $\begin{array}{l}\text { Tourism } \\
\text { management }\end{array}$ & $\begin{array}{l}\text { Management of remodelling, } \\
\text { decoration and } \\
\text { transformation }\end{array}$ & $\begin{array}{l}\text { Public security } \\
\text { management }\end{array}$ & $\begin{array}{l}\text { Emergency } \\
\text { warning }\end{array}$ \\
\hline Weight value & 4.9 & 4.7 & 4.5 & 4.6 & 4.5 & 3.8 & 4.1 & 4.3 & 4.5 \\
\hline Score & 3.5 & 3 & 4 & 2 & 5 & 1 & 2 & 4 & 5 \\
\hline Difference & 1.4 & 1.7 & 0.5 & 2.6 & -0.5 & 2.8 & 2.1 & 0.3 & -0.5 \\
\hline
\end{tabular}


Table 9. Weight values and scores of the first-layer indicators.

\begin{tabular}{|c|c|c|c|c|c|c|c|c|c|c|c|c|}
\hline Indicator & $\begin{array}{l}\text { Tangible } \\
\text { Heritage }\end{array}$ & $\begin{array}{l}\text { Intangible } \\
\text { Heritage }\end{array}$ & $\begin{array}{l}\text { Environmental } \\
\text { Improvement }\end{array}$ & $\begin{array}{l}\text { Community } \\
\text { Participation }\end{array}$ & $\begin{array}{l}\text { Community } \\
\text { Satisfaction }\end{array}$ & $\begin{array}{c}\text { Public } \\
\text { Consciousness of } \\
\text { Conservation }\end{array}$ & Employment & Profitability & $\begin{array}{l}\text { Types of } \\
\text { Business }\end{array}$ & $\begin{array}{l}\text { Planning and } \\
\text { Policies }\end{array}$ & Governance & $\begin{array}{c}\text { Risk } \\
\text { Managemen }\end{array}$ \\
\hline $\begin{array}{c}\text { Weight } \\
\text { value }\end{array}$ & 4.9 & 3.4 & 4.6 & 3.9 & 4.3 & 4.5 & 4 & 3.9 & 4.15 & 4.7 & 4.55 & 4.3 \\
\hline Score & 4 & 3 & 4 & 4.25 & 4 & 3.5 & 3 & 4 & 1.75 & 3.5 & 3.5 & 3 \\
\hline Difference & 0.9 & 0.4 & 0.6 & -0.35 & 0.3 & 1 & 1 & -0.1 & 2.4 & 1.2 & 1.05 & 1.3 \\
\hline
\end{tabular}




\section{Results and Discussion}

\subsection{Overall Evaluation of the Sustainability of Xijie}

Examining the resulting sustainability index value, of 3.45 points, for Xijie, it can be seen that the sustainability of the Xijie Historic District belongs to the mid-upper level of values, meaning that considerable improvements remain to be made.

The Conservational Plan of the Xijie Historic District won the National Award for Outstanding Urban and Rural Planning and Design, for representing a typical example of the combination of teaching and practice. Furthermore, owing to its unique historical and cultural characteristics, Xijie has become one of the most popular sites in the Dujiangyan City, attracting thousands of visitors every day (a record maximum of 20,000, average of 4000 per day). However, these achievements do not necessarily imply the sustainability of the development, and in-depth analysis is required, based on the sustainable development indicators.

\subsection{Evaluation of the Importance of Indicators for Sustainability through the Weight Values}

Considering the weight values of the first-layer indicators in Table 9, the indicator of tangible heritage had the highest value (4.9). The indicators of 'planning and policy', 'environmental improvement', 'governance', and 'public consciousness of conservation' also rank highly, indicating an increasing emphasis on the importance of managing and conserving the historic characteristics for sustainable development. Other indicator weight values point to slightly different expectations, except for 'intangible heritage' regarding traditional festivals and traditional handicrafts. 'Intangible heritage' had the lowest weight value of all the indicators (3.4), which reflects the common phenomenon in heritage conservation that the specialists still attach more importance to tangible heritage than intangible heritage, not to mention that the average person is more likely to be attracted by the physical landscapes.

\subsection{Evaluation of Conservation Performances through the Scores of Indicator}

Comparing the scores of the first-layer indicators in Table 9, 'community participation' received the highest score of 4.25. Next in descending order, with scores of 4, are 'tangible heritage', 'environmental improvement', 'community satisfaction', and 'profitability'. Other indicators received scores lower than 3.5, with 'types of business' garnering the lowest score of 2.4. This group of scores showed more satisfactory results with physical space improvements than the management and policy issues, in line with the long-term observations and investigations of the research team in the Xijie District. The post-earthquake reconstruction project launched a community-engaged revitalization approach, as discussed at the beginning of the paper, which demonstrated community involvement in the practice of historic preservation in China. Planning and conservation experts supervised the whole construction process, achieving positive outcomes in the physical environments. New businesses spread throughout the neighborhood, after the reconstruction. These included stores, however, most were restaurants and bars, which were noisy for the residents, especially at night. Additionally, the increasing number of entertainment facilities outside the historic area have diverted customers from the Xijie District, since 2015, while shops selling local specialities such as souvenirs, food, and drinks gradually replaced most restaurants and bars as more outside visitors came to the neighbourhood to experience its history and culture. This survey shows the lack of other business operations apart from commercial stores. Visitors tour the area in a hurried manner, within one to two hours, making it challenging to increase tourism spending. Meanwhile, the lack of facilities for daily life, such as grocery stores, inconveniences the residents.

Analyzing the scores in each of the four categories (Tables 5-8), the evaluation of the economic development presented a polarized state with scores of 1 and 5. This reflected the fact that the sustainability and local economic development in historic areas contains both mutually reinforcing and mutually exclusive contents. For instance, the development of the Xijie District contributes greatly to 
full-time and permanent employment (5 points), which however, does not mean that local employment is promoted ( 1 point). This is probably due to the fact that business owners prefer hiring experienced employees rather than training local residents. Therefore, special policies are required to provide employment opportunities for the locals. The evaluation converges most in the stakeholder dimension, which has a high correlation with the community involvement approach in the Xijie project.

\subsection{Evaluation of Prioritization for Sustainable Development}

Scores and weights should be considered together to prioritise conservation actions toward the sustainable development of historic districts-high weights with low scores must be considered as the highest priority, while low weights with high scores might be considered for suspension. Therefore, the order of priority ranking can be obtained by the differences between the weight values and the scores.

According to the differences in Table 9, the indicator of 'types of business' was the highest priority task, with a difference of 2.4, and had a degree of urgency far higher than 'risk management', which ranked second with a difference of 1.3. This reflects the potential threats to sustainability posed by the homogenization of business types, which has a negative impact on the historic environment, while contributing little to the residents' daily lives. Community involvement was calculated as a negative value listed at the bottom, however, this did not mean that community participation was unimportant; the weight given by the experts also guaranteed this point. Instead, the negative difference reflected the fact that the community participation performed well, and that there was no need to devote more resources to it, at this stage, due to the limitation of the conservation resources.

More accurate observations can be made by analysing the differences in the sub-indicators. For instance, the maximum difference of 3.2 was between the two sub-indicators of 'local employment' and 'local compatibility', which showed that more efforts were required to benefit the communities and match the characteristics of this District.

\section{Conclusions and Future Research}

Assessing conservation performance from a sustainability perspective is the primary step in conserving heritage for sustainable development. The resulting statistics from the sustainability evaluation model for the sustainability of the Xijie Historic District conservation remained consistent with the practical experience. The statistics present problems that are not easily perceived, and qualitative and quantitative assessment methods help explain these problems. The prioritization according to the differences helps to better invest the limited conservation resources in projects that are in urgent need of improvement. Therefore, the results demonstrate the validity and practicality of the sustainability evaluation model.

The sustainability evaluation model can be applied to various historic districts and regions. Its application should be subject to the following rules: (1) Weights of indicators should be modified by the researchers, with support from relevant experts; (2) although several times of evaluation may be applied in one case, the indicators should be kept the same, to allow comparison; and (3) different indicators are allowed, so long as the weights and values are obtained, ruled by the method and model in this study. The indicators system in this model, which reflects the conservation efforts, also provide a reference for the conservation and sustainable development of other heritage types.

In the research design, the finer the indicators division, the more accurate the exploration. However, the diverse characteristics of historic districts will reduce the versatility of the model. This study proposes a method of assigning weights of zero to exclude indicators that are not relevant to the characteristics of a case area.

Five steps are necessary for municipalities and local authorities to implement this evaluation model, according to the methodology of this study. First, developing the indicators regarding the case area; second, inviting experts to modify and assign weights to the indicators; third, designing targeted questionnaires and interviews, based on the indicators; fourth, identifying stakeholders, with whom to conduct questionnaire surveys, and collecting relevant data from planning, economic, public security, 
administrative management, and other departments; and fifth, calculation and analysis. In the case of Xijie, it took a four-person team, four months, to complete the entire evaluation process.

This study did not discuss all the resulting data of the indicators and the sub-indicators, but rather, it analyzed the representative ones, preferring to focus on the method and model. This research was also limited by its use of data from a single survey sample from 2018. A round of investigation was conducted in 2015, which was a comprehensive survey covering sustainable research and included a consistent set of questionnaires, in this study, however with its limited size of the sample (eleven to eighteen), it did not contain enough comparative data. Therefore, in future research, follow-up surveys should be conducted to develop a series of sustainability indices. By comparing changes in indices with changes in observations and professional criticism, the sustainability evaluation model could be validated and periodically revised.

Author Contributions: Conceptualization, H.K.; Methodology, H.K. and J.Z.; Validation, H.K., Formal Analysis, H.K. and J.Z.; Investigation, J.C., H.K.; Resources, H.K.; Data Curation, H.K.; Writing-Original Draft Preparation, H.K. and S.Z.; Writing-Review \& Editing, H.K. and S.Z.; Project Administration, J.C., J.Z. and H.K.; Funding Acquisition, H.K.

Funding: This work was funded by the National Natural Science Foundation of China (Grant No. 51678416); China scholarship Council (File No. 201606265070); Open Projects Fund of Key Laboratory of Ecology and Energy-saving Study of Dense Habitat (Tongji University), Ministry of Education(201820201).

Acknowledgments: We thank Nengbo Song, Wei Ren, and Nancy Coomer for their contributions to the research suggestion, data collection, and detailed comments to the paper.

Conflicts of Interest: The authors declare no conflict of interest.

Appendix A. Impact Indicators Weight Scale

\begin{tabular}{|c|c|c|c|c|c|c|}
\hline \multicolumn{7}{|c|}{ Heritage Conservation } \\
\hline Indicators & Sub-Indicators & $\begin{array}{c}\text { Very } \\
\text { Important }\end{array}$ & Important & $\begin{array}{l}\text { Moderately } \\
\text { Important }\end{array}$ & Of Little Importance & Unimportant \\
\hline \multirow{2}{*}{$\begin{array}{l}\text { Tangible } \\
\text { heritage }\end{array}$} & Historic layout & $\square$ & $\square$ & $\square$ & $\square$ & $\square$ \\
\hline & $\begin{array}{l}\text { Historic buildings and } \\
\text { elements }\end{array}$ & $\square$ & $\square$ & $\square$ & $\square$ & $\square$ \\
\hline \multirow{2}{*}{$\begin{array}{l}\text { Intangible } \\
\text { heritage }\end{array}$} & Traditional craftsmanship & $\square$ & $\square$ & $\square$ & $\square$ & $\square$ \\
\hline & Customs and festivals & $\square$ & $\square$ & $\square$ & $\square$ & $\square$ \\
\hline \multirow[t]{2}{*}{$\begin{array}{l}\text { Environmental } \\
\text { improvement }\end{array}$} & $\begin{array}{l}\text { Public facilities and } \\
\text { infrastructure }\end{array}$ & $\square$ & $\square$ & $\square$ & $\square$ & $\square$ \\
\hline & Public space and sanitation & $\square$ & $\square$ & $\square$ & $\square$ & $\square$ \\
\hline \multicolumn{7}{|c|}{ Stakeholder participation } \\
\hline \multirow{2}{*}{$\begin{array}{l}\text { Community } \\
\text { participation }\end{array}$} & Scope of participation & $\square$ & $\square$ & $\square$ & $\square$ & $\square$ \\
\hline & Depth of participation & $\square$ & $\square$ & $\square$ & $\square$ & $\square$ \\
\hline \multirow[t]{2}{*}{$\begin{array}{l}\text { Community } \\
\text { satisfaction }\end{array}$} & $\begin{array}{l}\text { Satisfaction with } \\
\text { implementation }\end{array}$ & $\square$ & $\square$ & $\square$ & $\square$ & $\square$ \\
\hline & Satisfaction with the results & $\square$ & $\square$ & $\square$ & $\square$ & $\square$ \\
\hline \multirow{2}{*}{$\begin{array}{c}\text { Public } \\
\text { consciousness of } \\
\text { conservation }\end{array}$} & Publicity and education & $\square$ & $\square$ & $\square$ & $\square$ & $\square$ \\
\hline & $\begin{array}{l}\text { Whole society's } \\
\text { participation in } \\
\text { conservation }\end{array}$ & $\square$ & $\square$ & $\square$ & $\square$ & $\square$ \\
\hline
\end{tabular}




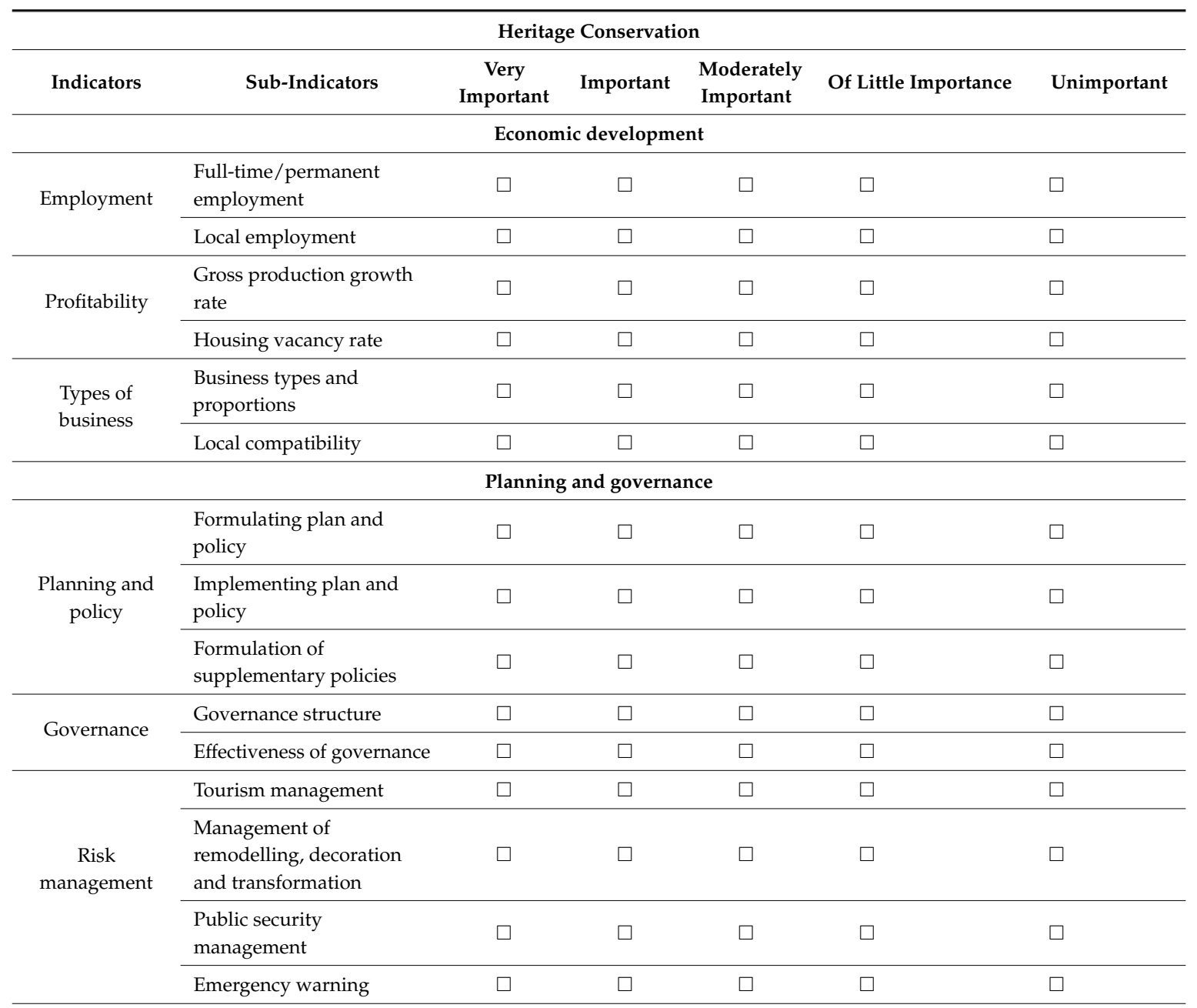

\section{Appendix B. Structure Modules of Questionnaires}

\section{Appendix B.1. Heritage Conservation (Module H)}

1. Do you think the traditional style of the neighbourhood has been maintained after the project?
A. maintained completely
B. maintained well
C. half maintained
D. little maintained

E. not maintained

2. Do you think the current architecture style matches the style before the earthquake?
A. all match
B. most match
C. half match
D. few match
E. none match

3. Do you think the historical details such as pavements are well kept?
A. all kept well
B. most kept well
C. half kept well
D. few kept well
E. none kept well

4. Do you think the traditional shops are still there?
A. all there
B. most there
C. half there
D. few there
E. none

5. Do you think that traditional craftsmanship was used during the reconstruction?
A. all the time
B. most of the time
C. half the time
D. seldom
E. never 
6. Do you think the traditional festivals have retained their original features?
A. retained well
B. mostly retained
C. half retained
D. seldom retained
E. not retained

7. Are you satisfied with the public facilities (restrooms, seating, etc.)?
A. very satisfied
B. mostly satisfied
C. half satisfied
D. little satisfied
E. never

8. Are you satisfied with the infrastructures (drainage, sewage, roads, etc.)?
A. very satisfied
B. mostly satisfied
C. half satisfied
D. little satisfied
E. never

9. Are you satisfied with the public space in this neighbourhood?
A. very satisfied
B. mostly satisfied
C. half satisfied
D. little satisfied
E. never

10. Are you satisfied with the cleaning of this neighbourhood?
A. very satisfied
B. mostly satisfied
C. half satisfied
D. little satisfied
E. never

Appendix B.2. Stakeholder Participation (Module S)

1. In which of the following activities have you participated?

A. Feedback for government policies before project implementation

B. Feedback for the planning

C. Housing design

D. Feedback for public space improvement

E. House construction supervision

F. Other

2. In what ways did you participate in the conventional reconstruction?

A. Was informed and asked for feedback

B. Opinions were accepted or got a satisfied reply

C. Cooperated with the government and experts to propose certain reconstruction plans (such as housing reconstruction design)

D. Made decisions on certain reconstruction aspects

E. Made decisions on involving in reconstruction or not

F. Other

3. Are you satisfied with the process of the organization and implementation of the Xijie project?
A. very satisfied
B. mostly satisfied
C. half satisfied
D. little satisfied E. never

4. Are you satisfied with the result of the Xijie project?
A. very satisfied
B. mostly satisfied
C. half satisfied
D. little satisfied E. never

5. Did you benefit from the conservational reconstruction of the Xijie Historic District?
A. benefited a lot
B. benefited some
C. benefited little
D. did not benefit
E. impacted badly

Could you please list what benefits you gained or lost?

6. Do you have a sense of belonging in the Xijie neighbourhood?
A. very much
B. often
C. so so
D. not often
E. never

7. What do you think about the organization of the publicity and educational activities of the Xijie Historic District conservation?
A. very good
B. good
C. so so
D. not so good
E. bad

8. What do you think about the enthusiasm of the public for participating in heritage conservation?
A. very good
B. good
C. so so
D. not so good
E. bad 
Appendix B.3. Economic Development (Module E)

1. How many households comprise the Xijie neighbourhood?

Among these, how many units are:

A. government properties; private properties; religious properties;

B. owned by occupants; self-employed business units; leased business units; public facilities (exhibition centres, cultural centres, management offices, firefighting offices, etc.); religious houses; vacant houses.

2. The total number of merchants and staff currently employed in the Xijie neighbourhood; among these:

A. How many merchants and staff live in this neighbourhood?

B. How many full-time employers and employees are there in commercial businesses (not including seasonal, temporary, or part-time staff)?

3. The population in the Xijie neighbourhood, except for commercial businesses (including residents, religious personnel, or other non-business personnel)?

4. The data of the gross product of the Xijie District in 2014-2017, respectively.

5. What business types are there in the Xijie District?

6. Do the business types match the characteristics of the District? Could they meet the needs of the residents?

Appendix B.4. Planning and Governance (Module G)

1. Please evaluate the 'Complete Plan of Conservation and Reconstruction of Dujiangyan Xijie Historic District', including, but not limited to, the principles and content of the Plan.

2. Was the 'Complete Plan of Conservation and Reconstruction of Dujiangyan Xijie Historic District' transparent to the public during the formulation and implementation stages?

3. Were all the plans effectively implemented?

4. Were there any amendments during the implementation of the Plan?

5. What are the major issues currently facing the implementation of the Plan?

6. Please comment on the Xijie District conservational reconstruction policy, 'Announcement of Implementing Conservatory Reconstruction and Housing Improvement'.

7. Was the policy of 'Announcement of Implementing Conservatory Reconstruction and Housing Improvement' transparent to the public during the formulation and implementation stages?

8. Were there any policy amendments or supplements during the implementation and after completion?

9. Is a complete Xijie District management structure established according to the Policy and the Plan?

10. Has a dedicated management office for the Xijie District been established?

If yes, then: A. Are there enough people employed in the management office?

B. Is the management office operating smoothly?

C. Does the management office have enforcement power over the Xijie District?

11. Before and after the implementation of the project, were the implementation and management timely and effective according to the Plan?

12. Before and after the implementation of the project, did the managers adjust the Plan effectively and in a timely manner to facilitate the project?

13. Is there a carrying capacity of tourists in Xijie? If so, how many days per year does the number of actual tourists exceed the carrying capacity? Does the Xijie District have official regulations to control the number of tourists entering the District?

14. Does the Xijie District have any formal regulations that restrict or punish tourists who damage public environmental facilities, or relics such as the ancient wall? 
15. Does the Xijie District have any formal regulations that restrict shop decorations and signage, owner alterations, or public space changes which damage the heritage environment?

16. Does the Xijie District have special public security regulation? How is the crime rate in the Xijie District compared to other neighbourhoods in the ancient town?

17. Has the Xijie District established an emergency management mechanism for heavy rains, mudslides, earthquakes, and fires?

18. After the reconstruction of Xijie District, has there been any other continuous investment in conservation or development?

\section{References}

1. Pesme, C. Contemporary Theory of Conservation. Stud. Conserv. 2005, 55, 315-316. [CrossRef]

2. Clark, K. Capturing the Public Value of Heritage: The Proceedings of the London Conference, 25-26 January 2006; Heritage: Swindon, UK, 2006.

3. Pereira Roders, A.; van Oers, R. bridging cultural heritage and sustainable development. J. Cult. Herit. Manag. Sustain. Dev. 2011, 1, 5-14. [CrossRef]

4. Maraña, M. Culture and Development. Available online: https://www.ehu.eus/documents/3120344/ 3356415/Culture_Development.pdf/837c2fac-4627-4a29-a21b-f41ddbf52ab2 (accessed on 15 October 2018).

5. United Nations Educational Scientific and Cultural Organization. Rio20 United Nations Conference on Sustainable Development 1-53. In Proceedings of the Future we Want: FInal Document of the Rio+20 Conference, Rio de Janeiro, Brazil, 20-22 June 2012.

6. United Cities and Local Governments (UCLG). Culture: Fourth Pillar of Sustainable Development. 2010. Available online: www.uclg.org (accessed on 10 November 2018).

7. Hawkes, J. The Fourth Pillar of Sustainability: Culture's Essential Role in Public Planning; Common Ground: Champaign, IL, USA, 2001.

8. To, K. Cultural Sustainability and Sustainable Communities Initiative in Developing Countries. Evidence from Vietnam and Indonesia; Nomos Verlagsgesellschaft mbH \& Co. KG: Baden-Baden, Germany, 2011.

9. Soini, K.; Birkeland, I. Exploring the scientific discourse on cultural sustainability. Geoforum 2014, 51, 213-223. [CrossRef]

10. Jin, Y. GIS-based and Statistical Approaches to Explore Relationship between Heritage and Urban Sustainable Development: A Cases Study on Liverpool, England; University College London: London, UK, 2018.

11. Murti, R. Natural Heritage-A Nature based Solution for Resilience to Disasters. In Proceedings of the 3rd International Symposium on Nature-Culture Linkages in Heritage Conservation in Asia and the Pacific: Disaster and Resilience, Tsukuba, Japan, 21 September-1 October 2018.

12. Guzmán, P.C.; Roders, A.R.P.; Colenbrander, B.J.F. Measuring links between cultural heritage management and sustainable urban development: An overview of global monitoring tools. Cities 2017, 60, 192-201. [CrossRef]

13. Landorf, C. Managing for sustainable tourism: A review of six cultural World Heritage Sites. J. Sustain. Tour. 2009, 17, 53-70. [CrossRef]

14. Verma, P.; Raghubanshi, A.S. Urban sustainability indicators: Challenges and opportunities. Ecol. Indic. 2018, 93, 282-291. [CrossRef]

15. Zhong, X.; Kou, H. Lessons from Post-Disaster Home Reconstruction: Dujiangyan City, China In Dynamics of Community Formation: Developing Identity and Notions of Home; Palgrave Macmillan: New York, NY, USA, 2017; pp. 99-118.

16. Heath, T.; Oc, T.; Tiesdell, S. Revitalising Historic Urban Quarters; Routledge: Abingdon, UK, 2013.

17. Council of Europe Treaty. Council of Europe Framework Convention on the Value of Cultural Heritage for Society; Faro Convention: Faro, Portugal, 2005.

18. Smith, L. Uses of Heritage; Routledge: Abingdon, UK, 2006.

19. Tweed, C.; Sutherland, M. Built cultural heritage and sustainable urban development. Landsc. Urban Plan. 2007, 83, 62-69. [CrossRef]

20. Fouseki, K. Values, Heritage and Sustainability; University College London: London, UK, 2017.

21. United Nations. Our Common Future: Report of the World Commission on Environment and Development—Brundtland Report; United Nations: New York, NY, USA, 1987. 
22. United Nations. The 2030 Agenda for Sustainable Development. 2015. Available online: https://www.un. org/sustainabledevelopment/cities / (accessed on 15 October 2018).

23. Nocca, F. The Role of Cultural Heritage in Sustainable Development: Multidimensional Indicators as Decision-Making Tool. Sustainability 2017, 9, 1882. [CrossRef]

24. UNESCO. World Heritage and Sustainable Tourism Programme. Available online: http://whc.unesco.org/ en/tourism/ (accessed on 15 October 2018).

25. ICOMOS. Cultural Heritage, the UN Sustainable Development Goals, and the New Urban Agenda. 2016, p. 23. Available online: http://www.usicomos.org/wp-content/uploads/2016/05/Final-Concept-Note.pdf (accessed on 15 October 2018).

26. Sharpley, R. Tourism and Sustainable Development: Exploring the Theoretical Divide. J. Sustain. Tour. 2000, 8, 1-19. [CrossRef]

27. Cole, D. Exploring the sustainability of mining heritage tourism. J. Sustain. Tour. 2004, 12, 480-494. [CrossRef]

28. Rodwell, D. Sustainability and the Holistic Approach to the Conservation of Historic Cities. J. Archit. Conserv. 2003, 9, 58-73. [CrossRef]

29. Wilson, L.A.; Boyle, E. Interorganisational collaboration at UK World Heritage Sites. Leadersh. Org. Dev. J. 2006, 27, 501-523. [CrossRef]

30. Ministry of Housing, Communities \& Local Government. Strategic Environmental Assessment and Sustainability Appraisal. Available online: https://www.gov.uk/guidance/strategic-environmentalassessment-and-sustainability-appraisal (accessed on 6 June 2018).

31. Pope, J.; Bond, A.; Hugé, J.; Morrison-Saunders, A. Reconceptualising sustainability assessment. Environ. Impact Assess. Rev. 2017, 62, 205-215. [CrossRef]

32. Ryberg, S.R. Neighborhood Stabilization through Historic Preservation: An Analysis of Historic Preservation and Community Development in Cleveland, Providence, Houston and Seattle; University of Pennsylvania: Philadelphia, PA, USA, 2010.

33. Snyder, M.R. The Role of Heritage Conservation Districts in Achieving Community Improvement; University of Waterloo: Waterloo, ON, Canada, 2008.

34. Yani, S.S.; Nidzam, R.M. Sustaining Cultural Heritage Through Heritage-Led Regeneration. In Islamic Perspectives Relating to Business, Arts, Culture and Communication; Springer: Berlin/Heidelberg, Germany, 2015; pp. 137-148.

35. Chatzi Rodopoulou, T.; Hein, C. Heritage-Led Regeneration in the UK: Preserving Historic Values or Masking Commodification? A Reflection on the Case of King's Cross, London; Delft University of Technology: Delft, The Netherlands, 2016.

36. Dragouni, M.; Fouseki, K.; Georgantzis, N. Community participation in heritage tourism planning: Is it too much to ask? J. Sustain. Tour. 2017, 26, 759-781. [CrossRef]

37. Ren, W. Developing A Sustainability Appraisal for Built Heritage Attractions; Oxford Brookes University: Oxford, UK, 2016.

38. Çetiner, O.; Gökyilmaz, A.Ç. Evaluation of the Sustainability on Cultural Heritage and Environmental Factors in Architecture from a Tourism Point of View: Ayvalik Historical City Center; Springer: Berlin/Heidelberg, Germany, 2010; pp. 179-186.

39. Timothy, D.J.; Nyaupane, G.P. Cultural Heritage and Tourism in the Developing World; Taylor \& Francis Group: Milton Park, UK, 2009.

40. Choi, H.; Sirakaya, E. Measuring residents' attitude toward sustainable tourism: Development of sustainable tourism attitude scale. J. Travel Res. 2005, 43, 380-394. [CrossRef]

41. Olsen, D.H. Cultural heritage and tourism in the developing world: A regional perspective. Tour. Manag. 2011, 32, 1236-1237. [CrossRef]

42. Ocampo, L.; Ebisa, J.A.; Ombe, J.; Geen Escoto, M. Sustainable ecotourism indicators with fuzzy Delphi method-A Philippine perspective. Ecol. Indic. 2018, 93, 874-888. [CrossRef]

43. Dean, M. Staged Authenticity: Arrangements of Social Space in Tourist Settings. Am. J. Sociol. 1973, 79, 589-603. [CrossRef]

44. DeCerteau, M. The Practice of Everyday life; University of California Press: Berkeley, CA, USA, 1984; pp. 131-149.

45. Ruan, Y. Preservation and Planning of the Historic Block. Urban Plan. Forum 2000, 2, 012. 
46. Boeri, A.; Gaspari, J.; Gianfrate, V.; Longo, D.; Pussetti, C. The adaptive reuse of historic city centres. Bologna and Lisbon: Solutions for urban regeneration. J. Technol. Archit. Environ. 2016, 230-237. [CrossRef]

47. Mingxia, L. Analysis on the Completion of the Outer Space Planning of Kuan Alley and Zhai Alley Historic District in Chengdu; Tsinghua University: Beijing, China, 2012.

48. Zeng, X.; Dai, L.; Xu, B.; Duper, K. Evaluation on the implementation of Historic District Conservation Planning-Taking Nanluogu Lane as an example. In Proceedings of the 2014 Annual Meeting of China's Urban Planning, Haikou, China, 13-15 September 2014; China Architecture \& Building Press: Beijing, China, 2014.

49. Zhang, J.; Niu, Z. The Principal Composition and Value Connotation of the Historical Districts. Urban. Archit. 2017, 18, 6-13.

50. Naoi, T. Visitors' evaluation of a historical district: The roles of authenticity and manipulation. Tour. Hosp. Res. 2004, 5, 45-63. [CrossRef]

51. Ruan, Y.; Lin, L. Authenticity in Relation to the Conservation of Cultural Heritage. J. Tongji Univ. Soc. Sci. Sect. 2003, 2, 1-5.

52. Ruan, Y.; Sun, M. The Study on Some Issues Related to the Conservation and Planning for the Historic Streets and Areas in China. City Plan. Rev. 2001, 10, 25-32.

53. Chen, Z.; Zhao, W. Reflections on Charter on the Built Vernacular Heritage. Time Archit. 2000, 3, 004.

54. Silverman, H.; Blumenfield, T. Cultural heritage politics in China: An introduction. In Cultural Heritage Politics in China; Springer: Berlin/Heidelberg, Germany, 2013; pp. 3-22.

55. Yang, J.R. Study on the Evaluation Method of the Implementation of Protection Planning for Historical and Cultural Blocks in Shichahai; Tsinghua University: Beijing, China, 2014.

56. Morar, C.; Dulca, M.; Nagy, G. Brownfields Regeneration, between Sustainable Urban Development and Cultural Heritage. the Former Military Sites in Oradea, Romania. J. Urban Reg. Anal. 2016, 8, 75.

57. Bell, S.; Morse, S. Sustainability Indicators: Measuring the immeasurable? J. Rural Stud. 2008, 16, $297-329$.

58. Stubbs, M. Heritage-sustainability: Developing a methodology for the sustainable appraisal of the historic environment. Plan. Pract. Res. 2004, 19, 285-305. [CrossRef]

59. Ren, W.; Han, F. Indicators for Assessing the Sustainability of Built Heritage Attractions: An Anglo-Chinese Study. Sustainability 2018, 10, 2504. [CrossRef]

60. Mitchell, G.; May, A.; McDonald, A.; Ecology, W. Picabue: A methodological framework for the development of indicators of sustainable development. Int. J. Sustain. Dev. 1995, 2, 104-123. [CrossRef]

61. Alberti, M. Measuring urban sustainability. Environ. Impact Assess. Rev. 1996, 16, 381-424. [CrossRef]

62. Mendes Zancheti, S.; Tone Ferreira Hidaka, L. Measuring urban heritage conservation: Indicator, weights and instruments (part 2). J. Cult. Herit. Manag. Sustain. Dev. 2012, 2, 15-26. [CrossRef]

63. Crance, J.H. Guidelines for Using the Delphi Technique to Develop Habitat Suitability Index Curves; US Fish and Wildlife Service: Washington, DC, USA, 1987.

64. Bai, X.; Roberts, B.; Chen, J. Urban sustainability experiments in Asia: Patterns and pathways. Environ. Sci. Policy 2010, 13, 312-325. [CrossRef]

65. Zhong, X.; Kou, H. The Influence of Community Participation on the Conservation of Historic Block: A Case Study of Post-Disaster Reconstruction of Xijie Historic Block. Urban Plan. 2015, 39, 87-94.

66. Kou, H.; Zhong, X. Reflection on Community Participation from the Perspective of HUL: A Case Study of Post-Disaster Reconstruction of Xijie Historic Block in Dujiangyan, Sichuan Province. In Operationalising the Historic Urban Landscape-A Practitioner's View; Tongji University Press: Shanghai, China, 2018; pp. 150-166.

67. Complete Plan of Conservation and Reconstruction of Xijie Historic Cultural District in Dujiangyan City; Tongji Urban Planning and Design Institute; Dujiangyan Urban Planning Bureau: Dujiangyan, China, 2009.

68. UNESCO World Heritage Centre. Recommendation on the Historic Urban Landscape; UNESCO World Heritage Centre: Paris, France, 2011.

69. Yin, R.K. Case Study Research: Design and Methods; Blackwell Science Ltd.: Hoboken, NJ, USA, $1994 ;$ p. 108.

70. Martin, T.G.; Burgman, M.A.; Fidler, F.; Kuhnert, P.M.; Low-Choy, S.; McBride, M.; Mengersen, K. Eliciting expert knowledge in conservation science. Conserv. Biol. 2012, 26, 29-38. [CrossRef] [PubMed] 
71. Super, D.E. The Work Values Inventory. Contemporary Approaches to Interest Measurement; University of Minnesoda Press: Minneapolis, MN, USA, 1973; pp. 189-205.

72. Denzin, N.K.; Lincoln, Y.S. Introduction: The Discipline and Practice of Qualitative Research; Sage Publications Ltd.: Thousand Oaks, CA, USA, 2005; pp. 1-32.

73. Locke, K. Qualitative research and Evaluation Methods. Nurse Educ. Today 2002, 23, 467.

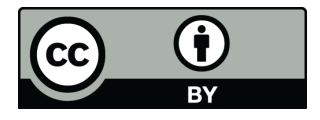

(c) 2018 by the authors. Licensee MDPI, Basel, Switzerland. This article is an open access article distributed under the terms and conditions of the Creative Commons Attribution (CC BY) license (http://creativecommons.org/licenses/by/4.0/). 